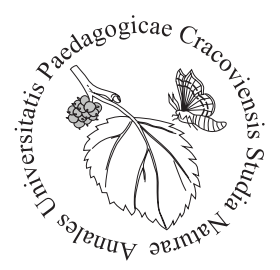

\author{
Anna Soltys-Lelek ${ }^{1 *}$, Wojciech Gruszka ${ }^{2}$ \\ ${ }^{1}$ Ojców National Park, 32-045 Sułoszowa, Ojców 9, Poland; 'ana_soltys@wp.pl \\ ${ }^{2}$ Department of Biological Sciences, Faculty of Physical Culture in Gorzów Wielkopolski., Poznań University School of Physical \\ Education, Estkowskiego 13, 66-400 Gorzów Wielkopolski, Poland
}

\title{
Occurrence of Rosa blanda Ait. (Rosaceae) in Poland
}

Introduction

Rosa blanda Ait. (sect. Cinnamomeae) is a North American species of rose, growing in Canada and the United States. Its natural range extends from Quebec to Ontario, south to Kansas, and east to Missouri and Ohio (Stephens, 1973; Gleason, Cronquist, 1991; Lewis et al., 2014). However, it has been cultivated and grown wild in Poland, Finland, Austria, Germany, and France (Tutin et al., 1968; Zieliński, 1987; Czarna, 2016; Rosa blanda Ait....). Mirek et al. (2002) granted R. blanda the status of an anthropophyte permanently established in Polish flora.

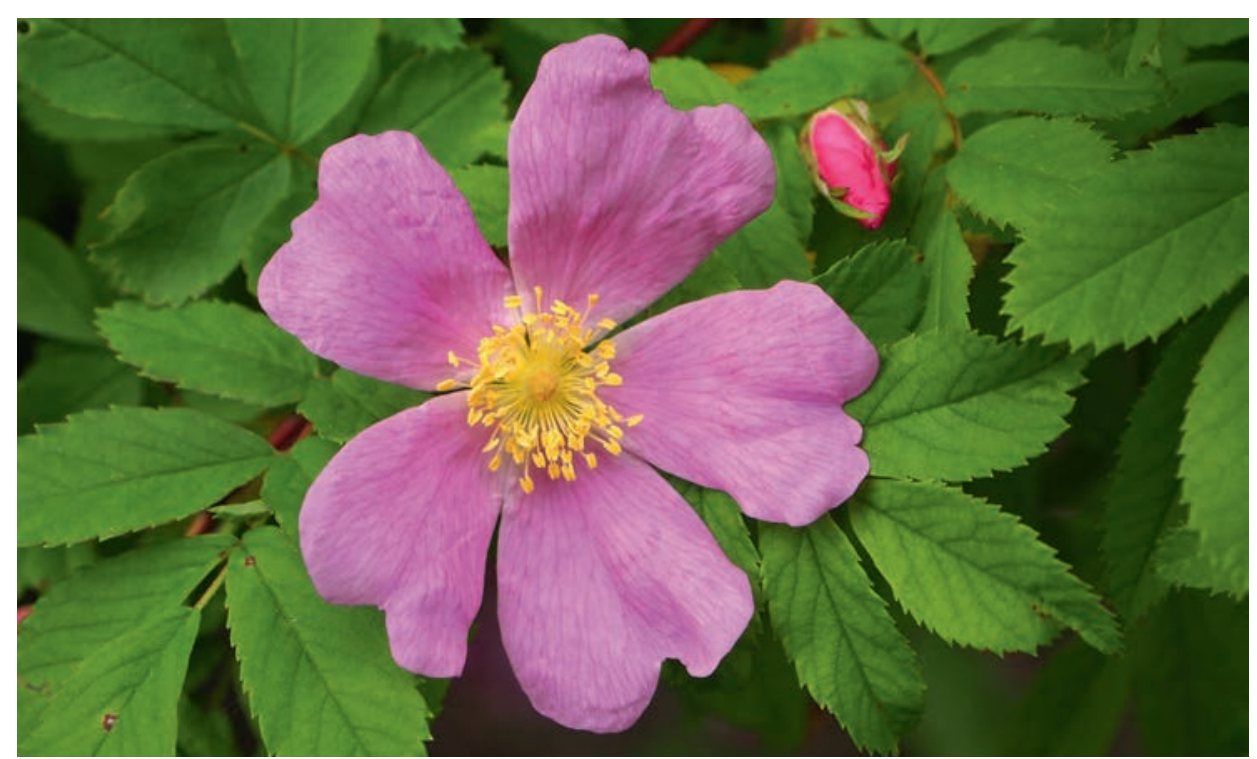

Fig. 2. Flower of Rosa blanda Ait. (Photo. 2013, W. Gruszka, Dendrological Garden in Przelewice) 
R. blanda is morphologically similar to the native species R. majalis Herrm., for which it is a vicarious species (Zieliński, 1987). Characteristic features of this rose are needle-like thorns at the base of long shoots; flowering stems usually without thorns; leaflets blade elliptic or ovate, sometimes obovate; margins 1-serrate; teeth 10-26 per side; acute; and inflorescences corymbs, 1-5(-10)-flowered (Stephens, 1973; Zieliński, 1987; Lewis et al., 2014; Minnesota Wildflowers a field...; Fig. 1 - Appendix 1, Fig. 2).

There is almost no information on the distribution of this species in the Polish botanical literature, probably due to the fact that, outside of cultivation in botanical gardens or arboreta, few specimens are seen. In 2017, during field research carried out in the vicinity of Gorzów Wielkopolski, the authors came across a site where $R$. blanda was growing in 17 different-sized clusters. This finding provided the impetus to undertake this research study aimed at presenting all the $R$. blanda sites in Poland so far identified and determining its ability to establish and spread.

\section{Materials and methods}

In order to establish the distribution of spontaneous sites of this species in the country, the authors, in addition to their own observations, consulted collections in the largest national herbariums via e-mail. Information was obtained from the following herbariums: the Herbarium of the Białowieża Geobotanical Station at the University of Warsaw (BSG), the Herbarium of the Institute of Dendrology of the Polish Academy of Sciences in Kórnik (KOR), the Scientific Herbarium of the University of Silesia (KTU), the Herbarium of the Institute of Botany at the Jagiellonian University in Cracow (KRA), the Herbarium of Vascular Plants at the Institute of Botany of the Polish Academy of Sciences (KRAM), the Herbarium of the Maria Curie-Skłodowska University (LBL), the Herbarium of the Faculty of Biology at the University of Warsaw (WA), and the Herbarium of the Department of Taxonomy and Plant Geography at the Nicolaus Copernicus University in Torun (TRN). Data published in papers by Zieliński $(1977,1987)$ and Czarna $(2009,2011,2016)$ and unpublished information made available by researchers, Prof. Błażej Gierczyk from the Adam Mickiewicz University in Poznań and Lucjan Rutkowski, PhD from the Nicolaus Copernicus University in Torun, were also included.

All the collected data are shown on the map (Fig. 3). The list of sites and the distribution map includes only sites that have been created spontaneously or those that are remnants of an old local cultivation (feral). Sites of specimens in private collections, botanical gardens, arboreta, etc. have not been recorded. The sites are located in relation to ATPOL (ATlas of POLand) squares, $10 \times 10 \mathrm{~km}$, (Zając, Zając, 2001) and the nearest village. Abbreviations used: obs. - observation, com. - compartment. 


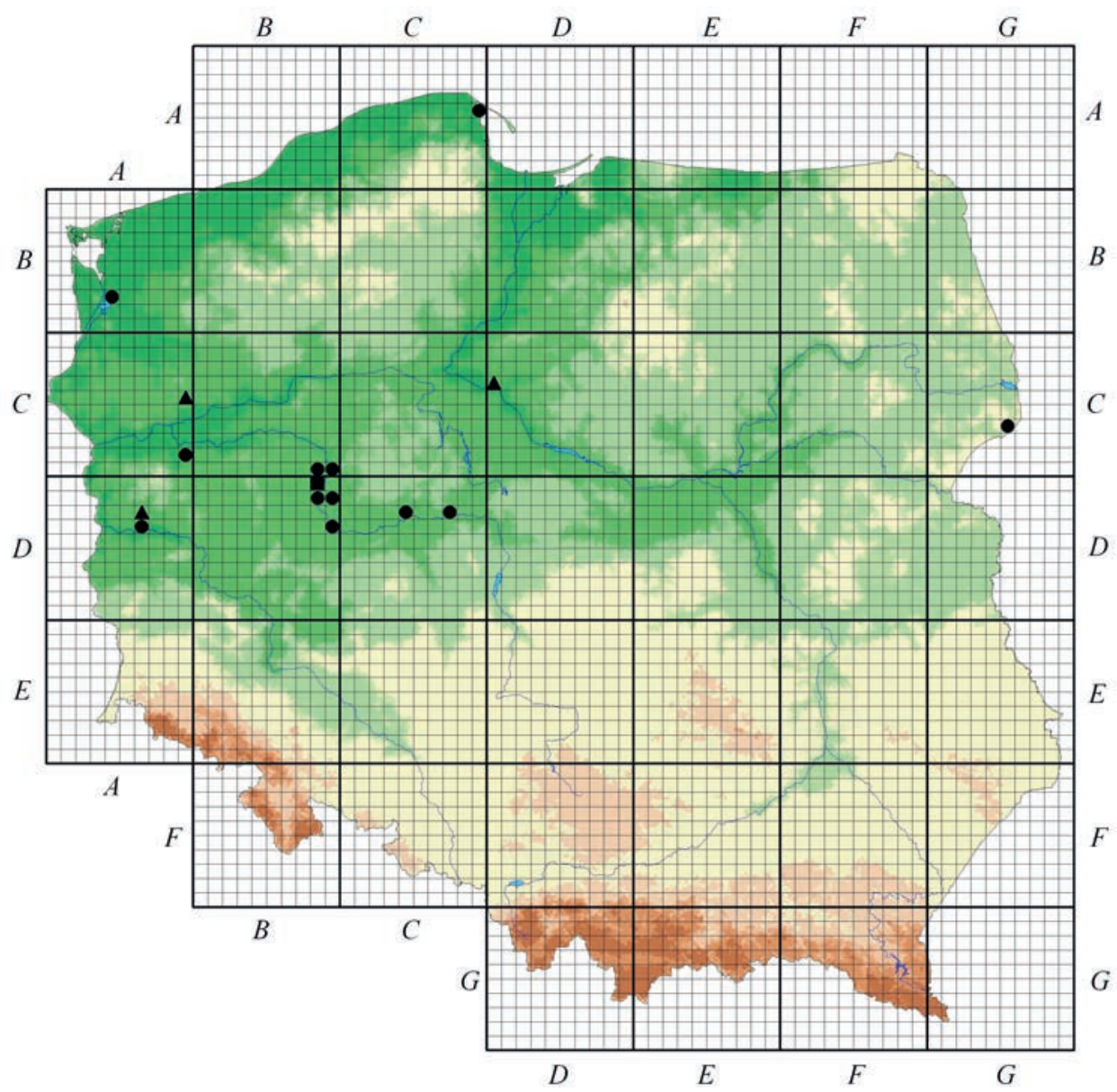

Fig. 3. Current distribution of Rosa blanda Ait. in Poland based on the ATPOL grid square system; $\bullet-$ squares in which single sites were recorded for the species, $\boldsymbol{\Delta}$ - squares in which two sites were recorded for the species, - squares in which four sites were recorded for the species

\section{Glossary of geographical names in article}

The list includes geographical coordinates for the villages in article:

Białowieża $52^{\circ} 42^{\prime} 04,9^{\prime \prime} \mathrm{N} ; 23^{\circ} 52^{\prime} 10,2^{\prime \prime} \mathrm{E}$ (GC65)

Budachów 52 $2^{\circ} 14,88^{\prime \prime} \mathrm{N} ; 15^{\circ} 5^{\prime} 3,56^{\prime \prime} \mathrm{E}$ (AD26)

Dobrosułów $52^{\circ} 11^{\prime} 37^{\prime \prime} \mathrm{N} ; 15^{\circ} 07^{\prime} 28,99^{\prime \prime} \mathrm{E}$ (AD26)

Konin $52^{\circ} 13^{\prime} 39^{\prime \prime} \mathrm{N} ; 18^{\circ} 15^{\prime} 41^{\prime \prime} \mathrm{E}(\mathrm{CD} 27)$

Poznań $52^{\circ} 24^{\prime} 52^{\prime \prime} \mathrm{N} ; 16^{\circ} 55^{\prime} 16^{\prime \prime} \mathrm{E}$ (BC98, BC99, BD08, BD18, BD19)

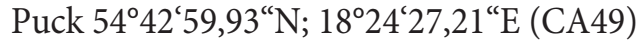

Pyzdry $52^{\circ} 10^{\prime} 13^{\prime \prime} \mathrm{N} ; 17^{\circ} 41^{\prime} 24^{\prime \prime} \mathrm{E}$ (CD24)

Skwierzyna $52^{\circ} 35^{\prime} 46,58^{\prime \prime} \mathrm{N}$; $15^{\circ} 30^{\prime} 10,38^{\prime \prime} \mathrm{E}$ (AC89)

Strzelce Krajeńskie 52 $52^{\prime} 43,22^{\prime \prime} \mathrm{N} ; 15^{\circ} 31^{\prime} 58,16^{\prime \prime} \mathrm{E}$ (AC49) 
Szczecin $53^{\circ} 26^{\circ} \mathrm{N} ; 14^{\circ} 34^{\circ} \mathrm{E}(\mathrm{AB} 74)$

Śrem $52^{\circ} 05^{\circ} \mathrm{N} ; 17^{\circ} 01^{\circ} \mathrm{E}(\mathrm{BD} 39)$

Toruń $53^{\circ} 02^{\prime} \mathrm{N} ; 18^{\circ} 37^{\prime} \mathrm{E}(\mathrm{DC} 30)$

Wielisławice $52^{\circ} 53^{\prime} 51,28^{\prime \prime} \mathrm{N} ; 15^{\circ} 27^{\prime} 58,91^{\prime \prime} \mathrm{E}$ (AC49)

Zemsko $52^{\circ} 16^{\prime} 20,0^{\prime \prime} \mathrm{N} ; 16^{\circ} 34^{`} 45,4^{\prime \prime} \mathrm{E}$ (AC89)

Results

\section{Unpublished sites in ATPOL grid squares}

AC4944, AC4955: between Strzelce Krajeńskie and Wielisławice, roadside trench, 2017, W. Gruszka,

AD2615: Dobrosułów near Torzym, 2010, A. Czarna, (KOR 52896),

BC9897: Poznań, $100 \mathrm{~m}$ from the intersection of Solidarności Avenue and Dojazd

Street, roadside, obs. 2019, B. Gierczyk (e-mail information),

BC9961: Poznań, Bożywoja Street, hedges, 2010, J. Zieliński, (KOR 48896),

BD0814: Poznań, near Żwirki and Wigury II Family Allotment Gardens, 800 m from

Bukowska Street, obs. 2019, B. Gierczyk (e-mail information),

BD0831: Poznań, at Owczej Street, near Marceliński Forest, com. 85lx, obs. 2019, B.

Gierczyk (e-mail information),

BD1883: Poznań, Greater Poland National Park, com. 76c, woodland, 2004, A. Purcel, 2004 (KOR 47092),

CD27: Konin, roadside slope, 1975, K. Balcerzak, 1975 (KOR 8975),

DC3021: Toruń, Pawia Street, remnant of former local cultivation, obs. 2019, L. Rut-

kowski (e-mail information), and

DC3061: Toruń, Sienkiewicza Street, remnant of former local cultivation, obs. 2019, L.

Rutkowski (e-mail information).

\section{Published sites in ATPOL grid squares}

AB74: Szczecin area, (Zieliński, 1987),

AC89: between Skwierzyna and Zemsko, remnant of former local cultivation (Zieliński, 1977),

AD2662: Budachów, on the road from Osiecznica (Zieliński, 1977),

AD3624: Lubuskie Lakeland, before Dobrosołów from Budachowo, remnant of an old hedge, 1974, J. Zieliński (KOR 6633, Zieliński, 1977),

BD0845: Poznań, old Górczyński cemetery, remnant of former local cultivation (Czar-

na et al., 2011; Czarna 2016),

BD0853: Poznań, near Junikowska Street, side of fence of plot no. 54, B. Gierczyk

11.06.2006 (Rosa blanda Aiton...),

BD19: Poznań area, (Zieliński, 1987), 
BD39: Śrem, hedges at the "Śrem" Iron Foundry (Czarna, 2009),

CA49: Puck area, (Zieliński, 1987),

CD2400: Pyzdry, old cemetery, remnant of former local cultivation (Czarna, 2016), and

GC6508: Białowieża, Białowieski National Park, Polana Białowieska, 1991, Ł. Łuczaj, Herbarium BSG Vascular Plants (catalogue number A20192) published in: Global Biodiversity Information Facility database (Rosa blanda Ait....).

Species were previously generally reported in the Białowieska Forest (Zieliński, 1987).

Discussion

Rosa blanda Ait. has the status of an established, non-invasive kenophyte in Poland. Its introduction into Poland is estimated to be 1817 (Tokarska-Guzik et al., 2012). Since the second half of the $20^{\text {th }}$ century, information about its sporadic spread beyond cultivation in gardens, arboreta, or botanical gardens has appeared in the literature (Zieliński, 1977, 1987).

R. blanda, as a foreign escapee species, is a rare species in Poland. A total of 22 sites, created spontaneously or as a remnant of old local cultivations, were identified. Its current range is mainly restricted to central and north-western Poland, with isolated sites in the north and east of the country (Fig. 3). However, it can be assumed that the distribution of the species in Poland is probably influenced by insufficient field research, particularly in the central and eastern part of the country. Therefore, it may be expected that the list of published sites will be supplemented with additional records in the future.

The spread of this species within the country may be facilitated by its wide tolerance, both in terms of climate and habitat conditions. R. blanda Ait. is a frost-resistant species; it tolerates temperatures to $-42.8^{\circ} \mathrm{C}$ (USDA zones 2 to 6; United States Department of Agriculture). It is also shade resistant. In Polish climatic conditions it blooms abundantly and bears fruit; it also propagates very effectively by stolons (authors' observation).

Usually occurring in sunny, dry to moist sites (Minnesota Wildflowers a field...), it tolerates dry, sandy habitats that are poor in nutrients, such as roadsides (Stephen, 1973) and heavy clay soils. In terms of $\mathrm{pH}$, it grows on acidic, alkaline, and neutral soils (Plants for a future...). Most often, it occurs in anthropogenic, partially transformed habitats (Tokarska et al., 2012).

Although rose has been included in the alien species list for Poland (Gatunki obce $w$ Polsce...) its negative impact on native species of flora or other elements of the habitats in which it grows has not yet been described. Nevertheless, the possibility that such impacts exist cannot be excluded. For many alien species a so-called delay phase, 
also known in the literature as a lag phase, has been observed between the appearance of the species and the discovery of its invasive behaviour (Hobbs, Humphries, 1995; Richardson, Pyšek, 2006). Therefore, it is important to know the current distribution of the plant's spontaneous sites and, in the long term, to undertake research aimed at determining its impact on the native flora. Furthermore, it has been proven that the species has a tendency to spontaneously cross with other species, for example $R$. acicularis Lindl., R. carolina L., and R. virginiana Mill. (Lewis, 2016; Lewis, Elvin-Lewis, 2017). A dangerous phenomenon may have been described by Mercure and Bruneau (2008) when they confirmed spontaneous crossing between $R$. blanda and $R$. rugosa Thunb. These are two species with great potential for range expansion that could pose a serious threat to the native flora. Although $R$. rugosa is widespread throughout Poland (and its abundance is increasing), as mentioned earlier, $R$. blanda occurs in few sites outside of cultivation. However, it should be noted that the hybrid form between R. rugosa and most probably R. blanda was observed by Zieliński (2014) in Poland in 1988; not as an F1 hybrid but as a next-generation segregant. In this context, it should be mentioned that $R$. blanda occurs in two places together with $R$. rugosa in the site between Strzelce Krajeńskie and Wielisławice, so the emergence of a hybrid between these species seems possible.

\section{Acknowledgements}

The authors would like to thank Prof. Jerzy Zieliński for the data sent from the herbarium of the Institute of Dendrology PAS in Kórnik. We would also like to thank Lucjan Rutkowski, PhD from the Nicolaus Copernicus University in Torun and Prof. Błażej Gierczyk, from the Adam Mickiewicz University in Poznań for making available their unpublished data.

Conflict of interest

The authors declare no conflict of interest related to this article.

References

Czarna, A. (2009). Rośliny naczyniowe środkowej Wielkopolski (Vascular plants of central Wielkopolska). Poznań: Wydawnictwo Uniwersytetu Przyrodniczego. 184 pp. [In Polish]

Czarna, A. (2016). Roses (Rosa spp.) in old cemeteries in the Wielkopolska region (Poland). Annales Universitatis Mariae Curie-Skłodowska, Sectio C, 71(2), 7-31. https://doi.org/10.17951/c.2016.71.2.7

Czarna, A., Woźnicka, A., Maj, M., Morozowska, M. (2011). Flora of vascular plants of selected Poznań cemeteries. Acta Agrobotanica, 64, 123-140. https://doi.org/0.5586/aa.2011.054

Gatunki obce w Polsce (Alien species in Poland). http://www.iop.krakow.pl/ias [In Polish]

Gleason, H.A., Cronquist, A. (1991). Manual of vascular plants of north-eastern United States and adjacent Canada (2nd ed.). New York: The New York Botanical Garden. 910 pp.

Hobbs, R.J., Humphries, S.E. (1995). An integrated approach to the ecology and management of plant invasions. Conservational Biology, 9, 761-770. https://doi.org/10.1046/j.1523-1739.1995.09040761.x

Lewis, W.H. (2016). Nomenclatural novelties in Rosa (Rosaceae) subgenus Rosa recognized in North America. Novon: A Journal for Botanical Nomenclature, 25(1), 22-46. https://doi.org/10.3417/2016018

Lewis, W.H., Elvin-Lewis, M. (2017). New records and range extensions for Rosa (Rosaceae) in North America. Journal of the Botanical Research Institute of Texas, 11(1), 185-191. 
Lewis, W.H., Ertter, B., Bruneau, A. (2014). Rosa. In: Flora of North America Editorial Committee (eds.), 1993+. Flora of North America North of Mexico. 19+ vols. New York and Oxford. Vol. 9.

Mercure, M., Bruneau, A. (2008). Hybridization between the escaped Rosa rugosa (Rosaceae) and native R. blanda in eastern North America. American Journal of Botany, 95(5), 597-607. https://doi. org/10.3732/ajb.2007385

Minnesota Wildflowers a field guide to the flora of Minnesota. https://www.minnesotawildflowers.info

Mirek, Z., Piękoś-Mirkowa, H., Zając, A., Zając, M. (2002). Flowering plants and pteriodophytes of Poland. A Checklist.. Kraków: Władysław Szafer Institute of Botany. Polish Academy of Sciences. 442 pp.

Plants for a future, earth, plants, people https://pfaf.org

Richardson, D.M., Pyšek, P. (2006). Plant invasions: merging the concepts of species invasiveness and community invasibility. Progress in Physical Geography: Earth and Environment, 30, 409-43. https:// doi.org/10.1191\%2F0309133306pp490pr

Rosa blanda Ait. In: Global Biodiversity Information Facility (GBIF) database. https://www.gbif.org/species/3002372

Rosa blanda Aiton, róża labradorska. W: Flora Polski atlas-roslin.pl. Rośliny naczyniowe dziko rosnące, uprawne, ozdobne gruntowe, mszaki (Rosa blanda Aiton, a Smooth rose. In: Polish flora atlas-roslin. pl. Vascular plants growing wild, cultivated, ornamental, ground, bryophytes). https://atlas-roslin.pl/ gatunki/Rosa_blanda.html [In Polish]

Stephens, H.A. (1973). Woody plants of the North Central Plains. Lawrence: University of Kansas Press. $530 \mathrm{pp}$.

Tokarska-Guzik, B., Dajdok, Z., Zając, M., Zając, A., Urbisz, A., Danielewicz, W., Hołdyński, C. (2012). Rośliny obcego pochodzenia w Polsce ze szczególnym uwzględnieniem gatunków inwazyjnych (Plants of foreign origin in Poland with particular emphasis on invasive species). Warszawa: Generalna Dyrekcja Ochrony Środowiska.

Tutin, T.G., Heywood, V.H., Burges, N.A., Moore, D.M., Valentine, D.H., Walters, S.M., Webb, D.A. (1968). Flora Europaea. Rosaceae to Umbelliferae. Volume 2. Cambridge: Cambridge University Press. 454 pp.

United States Department of Agriculture. https://planthardiness.ars.usda.gov/PHZMWeb/ (access: 2020).

Zając, A., Zając, M. (2001). Distribution atlas of vascular plants in Poland. Kraków: Laboratory of Computer Chorology, Institute of Botany, Jagiellonian University.

Zieliński, J. (1977). Roses of the Lubusz Upland. Fragmenta Floristica et Geobotanica, 23(2), 125-140.

Zieliński, J. (1987). Rosa L. In: A. Jasiewicz (ed.), Flora of Poland, 5, 48 pp. Kraków: Institute of Botany, Polish Academy of Sciences.

Zieliński, J. (2014). Dwa różne kultywary o nazwie Rosa 'Poznań' (Two different cultivars called Rosa 'Poznań). Rocznik Polskiego Towarzystwa Dendrologicznego, 62, 63-66. [In Polish]

\section{Abstract}

The article presents the Smooth rose, Rosa blanda Ait. distribution in Poland based on literature data, available herbarium materials, and shared unpublished data. R. blanda is a North American species that is cultivated and has become wild throughout Poland, where it has the status of a domestic, non-invasive kenophyte. This species is rare in Poland. Only 22 sites have been identified (mainly in the central and northwestern part of the country), as created spontaneously or as remaining from old, local cultivations. However, it cannot be excluded that this species will become invasive in the future and will negatively affect native flora species, especially through its ability to cross with other rose species (including invasive $R$. rugosa Thunb.).

Key words: Rosaceae, distribution of stands, invasive potential, kenophytes

Received: [2020.07.02]

Accepted: [2020.09.06] 
Streszczenie

W artykule przedstawiono rozmieszczenie w Polsce róży labradorskiej Rosa blanda Ait. na podstawie danych z literatury, dostępnych materiałów zielnikowych, a także udostępnionych danych niepublikowanych. $R$. blanda jest gatunkiem północnoamerykańskim, który jest uprawiany i zdziczał na terytorium całej Polski, gdzie posiada status zadomowionego, nieinwazyjnego kenofita. Gatunek ten jest rzadki w Polsce. Zidentyfikowano tylko 22 stanowiska (głównie w środkowej i północno-zachodniej części kraju), powstałe prawdopodobnie spontanicznie lub będące pozostałością starych, lokalnych upraw. Nie można jednak wykluczyć w przyszłości zachowania inwazyjnego i negatywnego wpływu na rodzime gatunki flory, zwłaszcza że gatunek ten ma tendencję do krzyżowania się z innymi gatunkami (w tym inwazyjną $R$. rugosa Thunb.).

Słowa kluczowe: Rosaceae, rozmieszczenie stanowisk, potencjał inwazyjny, kenofity

\section{Information on the authors}

Anna Soltys-Lelek https://orcid.org/0000-0002-9595-3167

Author of numerous scientific and popular science studies in the field of botany and environmental protection. Her research interests relate particularly to the critical type of rose (Rosa) and hawthorn (Crataegus). Member of the Polish and Slovak Botanical Society.

Wojciech Gruszka http://orcid.org/0000-0002-6229-8397

Author and co-author of scientific and popular science studies in lichenology and botany. His main research interests relate to the ecology and protection of lichen. In addition, he participates in the research on the distribution of representatives of the rose (Rosa) and hawthorn (Crataegus) species in Poland. 


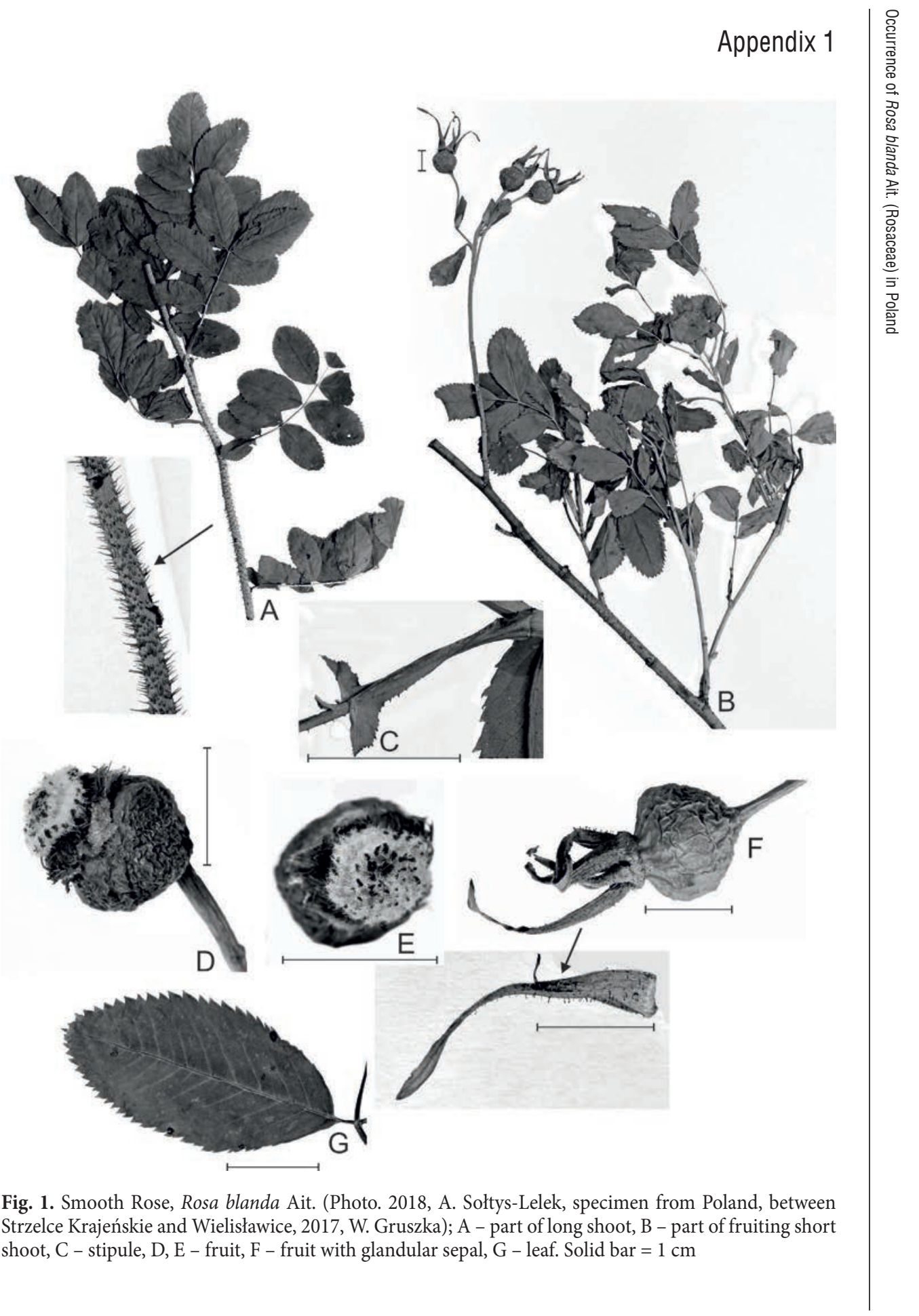

